\title{
Ischemic Stroke
}





\title{
Ischemic Stroke \\ Diagnosis and Treatment
}

\author{
Edited by Sheryl Martin-Schild, \\ Hen Hallevi, and Andrew Barreto
}

Rutgers University Press

New Brunswick, Camden, and Newark, New Jersey, and London 
Library of Congress Cataloging-in-Publication Data

Names: Martin-Schild, Sheryl, editor. | Hallevi, Hen, editor. | Barreto, Andrew, editor.

Title: Ischemic stroke : diagnosis and treatment / edited by Sheryl Martin-Schild, Hen Hallevi, and Andrew Barreto.

Other titles: Ischemic stroke (Martin-Schild)

Description: New Brunswick : Rutgers University Press, 2018. | Includes bibliographical references and index.

Identifiers: LCCN 2018030027| ISBN 9780813592572 (pbk.) | ISBN 9780813592589 | ISBN 9780813592596 | ISBN 9780813592602

Subjects: | MESH: Stroke-therapy | Stroke-diagnosis | Brain Ischemia-therapy | Brain Ischemia-diagnosis

Classification: LCC RC388.5 | NLM WL 356 | DDC 616.8/1—dc23

LC record available at https://lccn.loc.gov/2018030027

A British Cataloging-in-Publication record for this book is available from the British Library.

This collection copyright (C) 2018 by Rutgers, The State University of New Jersey

Individual chapters copyright (C) 2018 in the names of their authors

All rights reserved

No part of this book may be reproduced or utilized in any form or by any means, electronic or mechanical, or by any information storage and retrieval system, without written permission from the publisher. Please contact Rutgers University Press, 106 Somerset Street, New Brunswick, NJ 08901. The only exception to this prohibition is "fair use" as defined by U.S. copyright law.

The paper used in this publication meets the requirements of the American National Standard for Information Sciences-Permanence of Paper for Printed Library Materials, ANSI Z39.48-1992.

www.rutgersuniversitypress.org

Manufactured in the United States of America 